\title{
Adult Hippocampal Neurogenesis: A Coming-of-Age Story
}

\author{
H. Georg Kuhn, ${ }^{1,2 *}$ Tomohisa Toda, ${ }^{3,4 *}$ and Fred H. Gage ${ }^{3}$ \\ ${ }^{1}$ University of Gothenburg, Institute for Neuroscience and Physiology, Section for Clinical Neuroscience, 40530 Gothenburg, Sweden, ${ }^{2}$ Center for Stroke \\ Research Berlin and Neurocure Cluster of Excellence, Charité-Universitätsmedizin Berlin, 10117 Berlin, Germany, ${ }^{3}$ Laboratory of Genetics, Salk Institute for \\ Biological Studies, La Jolla, California 92037, and 4Paul F. Glenn Center for Biology of Aging Research at the Salk Institute, La Jolla, California 92037
}

\begin{abstract}
What has become standard textbook knowledge over the last decade was a hotly debated matter a decade earlier: the proposition that new neurons are generated in the adult mammalian CNS. The early discovery by Altman and colleagues in the 1960s was vulnerable to criticism due to the lack of technical strategies for unequivocal demonstration, quantification, and physiological analysis of newly generated neurons in adult brain tissue. After several technological advancements had been made in the field, we published a paper in 1996 describing the generation of new neurons in the adult rat brain and the decline of hippocampal neurogenesis during aging. The paper coincided with the publication of several other studies that together established neurogenesis as a cellular mechanism in the adult mammalian brain. In this Progressions article, which is by no means a comprehensive review, we recount our personal view of the initial setting that led to our study and we discuss some of its implications and developments that followed. We also address questions that remain regarding the regulation and function of neurogenesis in the adult mammalian brain, in particular the existence of neurogenesis in the adult human brain.
\end{abstract}

Key words: adult neurogenesis; aging; dentate gyrus; hippocampus

\section{Introduction}

Over the last two decades, numerous studies have demonstrated that a large majority of mammalian species retain the capacity for neurogenesis in the hippocampus into adult life. Our paper published in March 1996 (Kuhn et al., 1996), together with other concurrent studies, indicated the establishment of adult neurogenesis as a new research area, even though these studies were rediscoveries of a phenomenon described $>30$ years earlier by Altman, Bayer, Kaplan, and others (Altman and Das, 1965; Kaplan and Hinds, 1977; Bayer, 1983). Significant skepticism about the observation made in the early studies that new neurons are generated in the adult brain prevailed for decades. The main conceptual argument against the finding was that established neuronal networks would require stable neuronal elements and the addition of new elements would disturb network stability and thus cognition, a criticism that was later defused by computational network modeling (for review, see Deng et al., 2010) and behavioral studies (Dupret et al., 2008; Imayoshi et al., 2008;

Received Aug. 21, 2018; revised Oct. 21, 2018; accepted 0ct. 23, 2018.

This work was supported by National Institutes of Health R01 MH095741, National Institutes of Health U01 MH106882, G. Harold and Leila Y. Mathers Charitable Foundation, Leona M. and Harry B. Helmsley Charitable Trust Grant 2012-PG-MED00, Annette C. Merle-Smith, JPB Foundation, McKnight Foundation, Swedish Research Council Vetenskapsrådet K2015-63X-20117-10-4, Swedish Childhood Cancer foundation Barncancerfonden MT2017-0013, and Swedish governmental support under the LUA/ALF Agreement ALFGBG-72654. T.T. was supported by Japan Society for the Promotion of Science, the Kanae Foundation, and Paul F. Glenn Center for Biology of Aging Research. We thank Mary Lynn Gage for comments on the manuscript; Veronika Mertens for the illustration; and Drs. Sara B. Linker and Sarah Parylak for discussion.

The authors declare no competing financial interests.

*H.G.K. and T.T. contributed equally to this work.

Correspondence should be addressed to Dr. Fred. H. Gage, Laboratory of Genetics LOG-G, The Salk Institute for Biological Studies, 10010 N. Torrey Pines Road, La Jolla, CA 92037. E-mail: gage@salk.edu.

https://doi.org/10.1523/JNEUROSCI.2144-18.2018

Copyright $\odot 2018$ the authors $\quad 0270-6474 / 18 / 3810401-10 \$ 15.00 / 0$
Deng et al., 2009; Arruda-Carvalho et al., 2011). Methodologically, the earliest studies were hampered by the limitations of ${ }^{3} \mathrm{H}$-thymidine labeling and a scarcity of specific neuronal markers because immunohistochemistry was still under development. Conceptual and technological advances were thus key factors that ultimately established adult mammalian neurogenesis as a biological concept and generated several thousand publications in the years that followed.

In the early 1990s, we and others discovered that neural stem/ progenitor cells (NSPCs) could be isolated from embryonic brain tissue and propagated in vitro using defined cell culture media containing FGF-2 (Ray et al., 1993; Ray and Gage, 1994) or EGF (Reynolds et al., 1992). This was soon followed by in vitro propagation of neural stem cells from adult brain tissue (Reynolds and Weiss, 1992; Palmer et al., 1995) and provided a tangible foundation for the idea that new neurons are continually generated in the adult brain from endogenous NSPCs. High-efficiency isolation of neural stem cells from brain regions such as the dentate gyrus (DG) (Palmer et al., 1997) and the subventricular zone (Morshead et al., 1994) indicated to us that NSPCs had to exist in the adult rodent brain. Our group was also able to demonstrate that most brain areas seem to harbor progenitor cells that are capable of generating neurons and glial cells in vitro (Palmer et al., 1995, 1999), suggesting that brain regions with ongoing neurogenesis might retain not only NSPCs but also the proper molecular environment for neurogenesis, also referred to as the stem cell niche (Lim et al., 2000; Palmer et al., 2000).

The early in vitro studies were paralleled by investigations that not only replicated the observations by Altman and colleagues, but were first indications that adult neurogenesis was regulated in vivo by molecular cues. In a series of studies using ${ }^{3} \mathrm{H}$-thymidine labeling, Gould and Cameron studied the role of glucocorticoids 
and excitatory input to the dentate gyrus and gave first indications of the importance of stress and the hypothalamic-pituitaryadrenal-axis for hippocampal neurogenesis (Gould et al., 1992, 1994; Cameron et al., 1993, 1995). The study of adult neurogenesis intensified even more when novel histological labeling techniques, such as immunofluorescence against halogenated thymidine analogs in combination with cell-type specific markers, confocal microscopy and stereology, became available (for review, see Kuhn et al., 2016). Bromodeoxyuridine (BrdU) integrates into the DNA during the S-phase of the cell cycle, thereby permanently labeling cells that have undergone cell division during BrdU administration. The immunofluorescence detection of BrdU in conjunction with neuron-specific markers, such as NeuN, allowed high-resolution colocalization within individual cells with confocal microscopy and quickly became the gold standard for birthdating newly generated neurons in adult brain tissue (Kuhn and Cooper-Kuhn, 2007). Critique of this prevailing technique, which allows labeling of large cohorts of cells by systemic injection of BrdU, came from studies focusing on the possibility of false-positive labeling of cells undergoing DNA repair or aberrant cell division attempts under high stress load (Herrup and Yang, 2007). However, although it is conceivable that BrdU incorporation could lead to false-positive labeling, by taking appropriate precautions during BrdU labeling (Kuhn et al., 2016) and by applying additional detection methods, such as retroviral labeling, the generation of new neurons in the adult brain was unequivocally established.

Neurogenesis, whether observed in the embryonic or adult brain, comprises a cascade of cellular events leading to the generation of mature neurons. Lineage tracing to follow and dissect the individual steps has therefore been a crucial component of adult neurogenesis research. In vivo retroviral labeling is particularly informative because it requires nuclear membrane breakdown for stable integration of a reporter gene, which only occurs during cell division (Morshead et al., 1998; van Praag et al., 2002). It revealed cellular details, such as dendritic arborization and synaptic elements, that were previously largely missing from conventional immunohistochemical labeling of new neurons. But even more importantly, retrovirally labeled cells could be visualized in live brain slices and studied using electrophysiological methods (van Praag et al., 2002). Furthermore, the use of constitutive transgenic mouse lines with genetically encoded markers, such as Nestin promoter-based GFP-expressing mice, accurately represented NSPCs in the developing and adult nervous system and labeled a large majority of such cells (Yamaguchi et al., 2000; Kempermann et al., 2003; Encinas and Enikolopov, 2008). Finally, the development of inducible cre-lox systems permitted lineage tracing as well as lineage manipulations of developing cells in the adult brain (for review, see Enikolopov et al., 2015). Together, these tools have been extremely helpful in establishing the presence of neurogenesis in the adult brain of the numerous mammalian species studied so far, even though its existence had been heavily debated at the time (Gage, 1994, 2002).

\section{Neurogenesis in the aging brain}

Our initial paper from 1996 focused on the regulation of adult neurogenesis by age and found neurogenesis to be fully present in the 6-month-old rat (Kuhn et al., 1996). A drastic decrease in neurogenesis from adult stages toward later time points was observed; however, hippocampal neurogenesis was still detectable in the older rats (up to 27 months of age). The duration of adult neurogenesis was, at the time, acutely debated. Adult neurogenesis was seen by some as a remnant of embryonic development, declining to undetectable levels once development ended; others proposed it might provide a mechanism by which new neurons are continually added to the DG, regardless of age, to facilitate learning and memory processes. From this perspective, the hippocampus can also be seen as a brain region that never completes development. Although many changes occur in the local microenvironment of the brain during aging, newborn neurons appear to retain the potential to become fully mature and functional granule cells.

We observed a progressive decline of precursor cell proliferation during aging, with a decrease of $>80 \%$ occurring between 6 and 12 months of age and stabilizing at a low level thereafter. This finding raised competing hypotheses: (1) the hippocampal stem cell pool exhaust with age; (2) the aging microenvironment does not provide the molecular cues for further proliferation; or (3) the aging stem/progenitor cells become unresponsive to environmental cues. The first hypothesis would imply that the hippocampal stem cells are depleted with time, a model that was put forward by Encinas et al. (2011), who showed that increasing numbers of astrocytes are generated from activation of quiescent neural stem cells with age. However, Song and colleagues showed that individual neural stem cells are able to undergo activation, return to quiescence and reactivation with limited depletion via astrocytic transformation (Bonaguidi et al., 2011). An increasing number of studies has focused on the second hypothesis and revealed changes in the local microenvironment as well as the systemic milieu with age involving increasing levels of inhibitory molecules or decreasing levels of neurogenesis-promoting factors (Smith et al., 2018; for recent reviews, see Mosher and Schaffer, 2018). But importantly, even at late stages of aging, hippocampal neurogenesis can be stimulated by exposing animals to both physically and mentally stimulating environments (Kempermann et al., 1998, 2002; van Praag et al., 2005; Kronenberg et al., 2006). Last, the intrinsic responsiveness of neural stem cells may also be altered due to epigenetic changes. Epigenetic mechanisms are crucial components of adult neurogenesis (Jobe et al., 2012) and changes have been observed with age (Kuzumaki et al., 2010a,b; Horvath et al., 2012). All together, what began with the observation of neurogenesis decline has led to intensive and still ongoing research of the molecular mechanisms leading to the age-related changes in hippocampal neurogenesis; and while different hypotheses are on the table, it appears highly likely that several signaling pathways are involved.

\section{New technologies to address the aging of adult hippocampal neurogenesis}

As mentioned earlier, transgenic approaches have been among the most powerful tools to visualize the process of adult neurogenesis and to dissect out the genetic and environmental factors that influence adult hippocampal neurogenesis in rodents. A number of transgenic mouse lines with fluorescent proteins or a Cre recombinase enzyme under the control of cell-type-specific promoters, such as the Nestin, Hes5, hGFAP, and Sox 2 promoters, have been used to selectively label NSPCs and their progeny or to delete target genes in those populations in vivo (Yamaguchi et al., 2000; Lagace et al., 2007; Suh et al., 2007; Imayoshi et al., 2008). Many studies have provided significant insights into the maintenance and aging of adult hippocampal neurogenesis (Suh et al., 2007; Lugert et al., 2010; Bonaguidi et al., 2011, 2012; Encinas et al., 2011; Kempermann, 2015; Toda et al., 2018). However, observations using fixed tissues constrain our view of the dynamic processes of adult neurogenesis to fragmented timeseries sampling. To overcome this technical hurdle, recently, we 
and others developed a novel methodology to image the DG in awake, behaving mice using multiphoton microscopy (Danielson et al., 2016, 2017; Gonçalves et al., 2016b; Pilz et al., 2016; Kirschen et al., 2017). These live-imaging systems enable us to continuously visualize the dynamics of adult neurogenesis, neuronal maturation, and neural activity in the DG with less fragmentation. Most recently, Jessberger's group successfully traced the process of adult neurogenesis from a subpopulation of adult NSPCs to neurons over 2 months in the live adult mouse hippocampus using multiphoton imaging (Pilz et al., 2018). Liveimaging of adult hippocampal neurogenesis uncovered a variable neurogenic competency, survival rate, and fate commitment among cell clones, which have been difficult to estimate with fixed tissue. Similarly, live-imaging developing dendrites of adult-born dentate granule cells revealed an unexpected homeostatic dendritic pruning process in which facilitation of dendritic branching by an exposure to enriched environmental is counteracted by earlier and more intensive pruning (Gonçalves et al., 2016b). Future experiments using long-term live imaging will reveal more precise dynamics of the aging process in adult neurogenesis, including when the development of DG stops and when the aging of adult neurogenesis starts, as well as the heterogeneous nature of adult NSPCS, the effects of environment and genetic factors.

In parallel with live imaging, recent progress in single-cell RNA sequencing with optimized next generation sequencing technology provides a higher-resolution view of cellular heterogeneity and better insight into the function of an individual cell (Shin et al., 2015; Habib et al., 2016; Lacar et al., 2016; Artegiani et al., 2017; Yuzwa et al., 2017; Hochgerner et al., 2018; Jaeger et al., 2018). This technology allows us not only to resolve the heterogeneous nature of the transcriptome but also to capture developmental dynamics, the effects of environmental changes on a specific population, and the differences in cellular state within the same population. The evolution of single-cell technology is now pushing forward our understanding of the complex nature of adult neurogenesis.

In addition to live-imaging and sequencing technology, molecular tools to manipulate the process of adult neurogenesis have been evolving. Viral tools, including retroviral, lentiviral and adeno-associated viral tools, have been widely used to label adultborn cells and manipulate genes of interest in these populations (Lie et al., 2005; Tashiro et al., 2006; Zhao et al., 2006; Kirschen et al., 2017). These viral tools can also express optogenetic (e.g., channelrhodopsins, halorhodopsins) (Gu et al., 2012; Danielson et al., 2016; Zhuo et al., 2016) and chemogenetic proteins (e.g., the synthetic receptor hMd3 and synthetic ligand clozapine- $N$ oxide) (Alvarez et al., 2016; Anacker et al., 2018) to selectively manipulate neural activity in a specific population at a specific time. In combination with a retrograde rabies-viral tracing methodology (Wickersham et al., 2007), this research has revealed the dynamic reorganization of circuitry of adult-born neurons during maturation (Vivar et al., 2012; Deshpande et al., 2013; Bergami et al., 2015; Alvarez et al., 2016; McAvoy et al., 2016; Sah et al., 2017). For example, local and long-distance afferents from local interneurons and cortical neurons onto newborn DG neurons were significantly increased with environmental enrichment (Bergami et al., 2015), and optogenetic and chemogenetic tools helped to reveal that disynaptic circuits via local interneurons mediated the effect of environmental enrichment (Temprana et al., 2015; Alvarez et al., 2016). In addition to manipulating neural activity, the evolution of optogenetic tools has enabled us to manipulate several biological processes, including protein local- ization, protein degradation, organelle transport, signaling pathways, and gene regulation (Imayoshi et al., 2013; Rost et al., 2017), any of which could be manipulated for the direct regulation of adult neurogenesis.

New technology always brings us novel insights. There are more ongoing technological developments in areas, such as single-cell proteomics/genomics and computational modeling. Implementation of new technologies will surely uncover heretofore unrecognized aspects of adult hippocampal neurogenesis and reveal how aging of the whole organism affects the neurogenesis process (Fig. 1).

\section{Roles of environment in the aging of adult neurogenesis}

One prominent feature of adult hippocampal neurogenesis is that an animal's experiences impact the neurogenesis process. Positive experiences, such as learning, exposure to enriched environment, and physical activity, can partially reverse the agerelated decline of neurogenesis (Kempermann et al., 1997; Gould et al., 1999a; van Praag et al., 1999, 2005; Kempermann, 2015). In addition, other environmental components, such as stress, diet, sleep, and life events, have significant impacts on adult hippocampal neurogenesis as reported and reviewed by others (Gould et al., 1998; Mirescu et al., 2004; Stangl and Thuret, 2009; Leuner and Gould, 2010; Snyder et al., 2011; Anacker and Hen, 2017). In this review, we focus on aging, which is an unavoidable biological process that gradually compromises brain function and plasticity, including adult neurogenesis-dependent structur$\mathrm{al} /$ functional plasticity and mood regulation in the hippocampus. Therefore, understanding how environmental factors can potentiate brain plasticity through the activation of adult neurogenesis has been a fundamental challenge. The proliferation rate of NSPCs, the fraction of adult-born cells that differentiate into neurons, and the survival rate of adult-born neurons are all significantly decreased with age, presumably due to both cellintrinsic and cell-extrinsic changes (Renault et al., 2009; Lugert et al., 2010; Encinas et al., 2011; Yousef et al., 2015; Leeman et al., 2018). These include changes in metabolic status, transcriptional and epigenetic programs, hormonal regulation, systemic milieu, and neurotrophic signaling (Kuhn et al., 1996; Cameron and McKay, 1999; Villeda et al., 2011, 2014; Kuipers et al., 2015; Moore et al., 2015; Yousef et al., 2015; Corenblum et al., 2016; Beckervordersandforth et al., 2017; Castellano et al., 2017). The reduction of neurogenic capability can be partially reversed by environmental enrichment and physical activity, reducing corticosteroid levels as well as systemic factors transferred from young to old animals (Falkenberg et al., 1992; Kempermann et al., 1998, 2002; Cameron and McKay, 1999; Imayoshi et al., 2008; Villeda et al., 2011, 2014; Speisman et al., 2013; Yousef et al., 2015; Castellano et al., 2017). The exact mechanisms by which environmental enrichment, physical exercise, and systemic milieu from young animals potentiate neurogenesis are not clear yet, but presumably they include neurotrophic, Wnt/FGF, neurotransmitters, and MHC signaling (Oliff et al., 1998; Imayoshi et al., 2008; Kobilo et al., 2011; Okamoto et al., 2011; Vivar et al., 2013; Kang and Hébert, 2015; Smith et al., 2015; Fan et al., 2017). A recent report demonstrated that aging also delays the maturation and integration of adult-born neurons (Trinchero et al., 2017), even though the morphological features of new neurons in the aged brain are similar to those generated in the young brain (van Praag et al., 2005). It is not clear whether this age-dependent delay is beneficial for the aging brain, but the delayed morphological maturation and synaptic integration can be reversed by enhancing neurotrophic signaling or physical activity (Trinchero et al., 


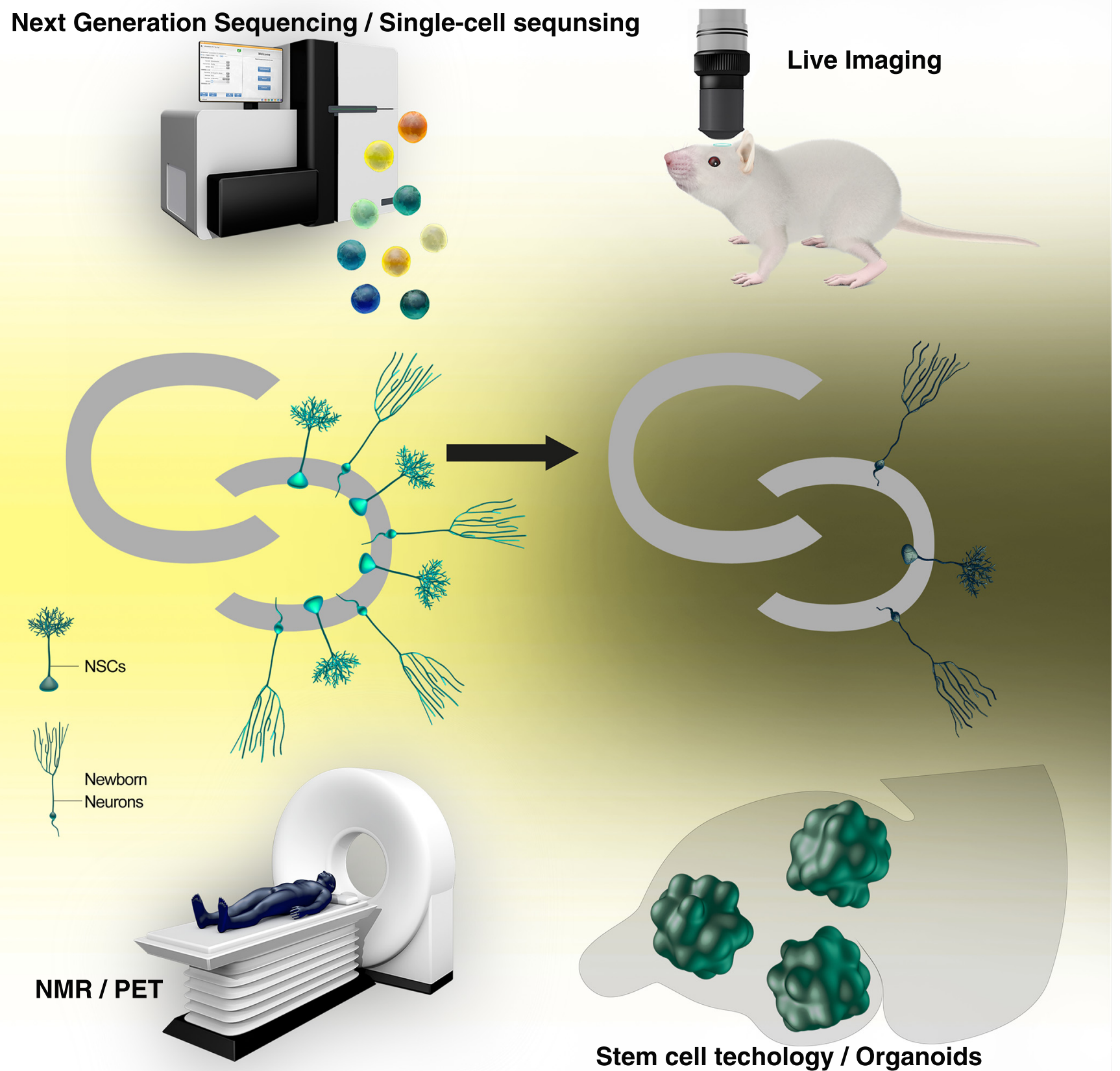

Figure 1. A schematic view of implementation of emerging technology to study adult hippocampal neurogenesis throughout the life span. Technology that will be implemented to study adult hippocampal neurogenesis is next generation sequencing/single-cell sequencing (top left), live imaging (top right), noninvasive imaging (e.g., NMR, nuclear magnetic resonance spectroscopy or PET, positron emission tomography) (bottom left), and stem cell technology/organoids (bottom right), but not limited to these technologies.

2017). It is likely that other, yet unknown factors involved in aging contribute to this delay. These factors would include not only local environmental changes in the brain, such as decreased synaptic activity, reduced neurotrophic factors, reduced mitochondrial activity, and age-dependent inflammation, but also systemic changes induced by a lack of mobility and altered metabolism in aged animals themselves. Further work will uncover which age-dependent changes compromise which steps of adult neurogenesis.

Interestingly, the mechanisms underlying the maintenance of adult NSPCs and the effect of aging on that process seem to be different across neurogenic niches (Molofsky et al., 2006; Lim et al., 2009). An increased expression of p16INK4a in neural pro- genitors of subventricular zone significantly affected neurogenic capability but did not affect neurogenic functions in the DG (Molofsky et al., 2006). This could be due to an intrinsic difference in adult NSPC populations, distinct environmental changes, or both. It would be interesting to examine whether differences between neurogenic regions are evolutionally conserved or, even conversely, vary depending on species.

\section{Adult hippocampal neurogenesis in the human brain}

The first evidence of adult hippocampal neurogenesis in the human brain was demonstrated by using the gold-standard BrdU labeling of dividing cells with cell-type-specific markers, such as NeuN and GFAP, to identify BrdU-positive adult-born neurons 
by confocal microscopy (Eriksson et al., 1998). Since then, using immunohistochemical, carbon ${ }^{14}$ birth dating and tissue culture techniques, several independent laboratories have found evidence of adult hippocampal neurogenesis in the DG of the human hippocampus (Roy et al., 2000; Palmer et al., 2001; Knoth et al., 2010; Spalding et al., 2013; Dennis et al., 2016; Mathews et al., 2017; Boldrini et al., 2018), as well as in nonhuman primates (Gould et al., 1999b; Kornack and Rakic, 1999; Leuner et al., 2007). In addition, adult hippocampal neurogenesis in the DG is highly conserved across mammalian species with few exceptions (Patzke et al., 2015), implying significant roles for adult hippocampal neurogenesis in brain function. Many studies have shown an exponential reduction of hippocampal neurogenesis along with aging despite the fact that molecular signatures of continuous adult neurogenesis and proliferation have been found (Knoth et al., 2010; Spalding et al., 2013; Dennis et al., 2016; Mathews et al., 2017). Given the size of the adult human DG $\left(500-150 \mathrm{~mm}^{3}\right)$ and the number of newborn neurons identified per day by a carbon dating method ( $\sim 700$ cells) (Spalding et al., 2013; Dillon et al., 2017), one can assume that adult neurogenesis in the human DG is sparse. The decline of adult hippocampal neurogenesis with age could attenuate forms of structural and functional plasticity, and the level of adult hippocampal neurogenesis has been linked to cognitive abilities both in rodents and nonhuman primates (Aizawa et al., 2009). Hippocampusdependent cognitive abilities also decline with age in humans (Yassa et al., 2011), but it is not clear yet whether the levels of adult neurogenesis correlate with cognitive abilities in humans.

Recently, using an unbiased stereology method with several common markers of neurogenesis, Boldrini et al. (2018) showed that healthy human brains maintained similar levels of neurogenesis from 14 to 79 years of age, raising the possibility of higher neural plasticity in the human DG than was expected from previous studies. However, in contrast, Sorrells et al. (2018) used the same markers (DCX, PSA-NCAM) but reached a different conclusion, suggesting that neurogenesis in the human DG quickly decreased after birth and became undetectable before adulthood. Where does this contradiction come from?

One possible explanation is technical differences between the studies, including the duration of postmortem delay, fixation and sample preservation methods, and staining protocols. These factors are critical to reliably detect markers of adult-born neurons. The duration of postmortem delay in particular is crucial not only for the detection of DCX, but also the morphology of DCX signals (Boekhoorn et al., 2006). Sorrells et al. (2018) used brains with longer postmortem delays (up to $48 \mathrm{~h}$ ) compared with other studies (Eriksson et al., 1998; Boldrini et al., 2018), which could be a critical factor in underestimating the number of adult-born neurons. Another major difference was the use of stereology (Boldrini et al., 2018), a method for unbiased quantification in $3 \mathrm{D}$ tissues from serial sections. The method provides accurate estimation in terms of the number of adult-born neurons compared with counting cells from a few sections of tissues, and it has been adapted to study adult neurogenesis in rodents (Kuhn et al., 1996; Kempermann et al., 1997). Usage of stereology should be encouraged to obtain an accurate picture of adult neurogenesis in the human brain.

In addition, the criteria used for defining adult-born neurons in the human brain were different in the two studies. Sorrells et al. (2018) defined only $\mathrm{DCX}^{+} \mathrm{PSA}^{-\mathrm{NCAM}^{+}}$cells as adult-born neurons; they did not count $\mathrm{DCX}^{-} \mathrm{PSA}-\mathrm{NCAM}^{+}$cells, claiming that the latter exhibited more mature morphological features based on their criteria. However, the developmental time course of adult-born neurons in the human DG has not been clearly characterized, and neurons in higher mammals take at least 6 months to fully mature (Kohler et al., 2011). Furthermore, our knowledge of the markers of adult-born neurons has been derived from studies using rodent models; therefore, we do not know the exact expression time course of neuronal markers in adult-born neurons in the human DG. In addition, adult-born DG neurons show slower kinetics of maturation/survival and different patterns of genetic programs/marker expression compared with perinatally born DG neurons in rodents (Dayer et al., 2003; Shi et al., 2004; Overstreet-Wadiche et al., 2006; Jessberger et al., 2008; Andersen et al., 2014; Urbán and Guillemot, 2014; Cahill et al., 2017). Based on these technical limitations, many researchers in the field, including us, questioned the strong conclusion from Sorrells et al. (2018; see also Kempermann et al., 2018). The discrepancies between these studies underscore that we need to clearly determine the expression time course of neurogenesis markers in the human DG. Importantly, there are still many open questions as discussed below. We believe that this debate stimulates and facilitates the field to develop advanced means as well as a technical standard to move the research of human adult hippocampal neurogenesis forward.

\section{The future comes with more questions}

Since the discovery of adult hippocampal neurogenesis, remarkable progress has been made in understanding the molecular mechanisms and functional contributions of adult neurogenesis. However, we still have fundamental questions that need to be resolved. Here we summarize and discuss some of these questions.

First, although adult neurogenesis declines with age, it is still not clear how the dynamics of adult neurogenesis are affected by aging. Such dynamics include the activation of quiescent adult NSPCs as well as the differentiation, maturation, and integration of adult-born cells. Because adult NSPCs seem to be a heterogeneous population (Jhaveri et al., 2015; Pilz et al., 2018), a distinct subpopulation may be differently affected by aging. Using multiphoton imaging, long-term live imaging of adult hippocampal neurogenesis throughout the entire life of animals (both in rodents and nonhuman primates) would reveal the nature of adult hippocampal neurogenesis in aging. Along the same line, we need to understand the heterogeneous nature of adult NSPCs and their progeny. It would be intriguing to examine whether distinct populations of adult NSPCs generate different subtypes of dentate granule cells, whether they differentially respond to environmental stimuli, how genetic and epigenetic regulations differ between subtypes, and whether the heterogeneity of adult hippocampal neurogenesis is preserved during evolution. Single-cell technologies, including single-cell RNA-seq, single-cell epigenetic methods, and single-cell proteomics, will be promising approaches to address these questions. The same approaches can be applied to pathological conditions as well to reveal the effect of pathology for each individual cell type.

Second, the developmental time course of adult-born neurons in the human brain needs to be determined. In the case of nonhuman primates, it takes at least several months to express mature neuron markers (Kohler et al., 2011), which means that it could take longer than several months for them to be fully mature. Given that humans have longer developmental time courses and lifetimes, it is reasonable to speculate that the maturation process of adult-born neurons in the human hippocampus should take longer. Characterizing the maturation process along with the expression of molecular markers is critical because most studies in the human brain rely on using the postmortem brain. 
However, as we discussed above, we do not know exactly which markers correspond to which developmental time points in human adult-born neurons. Furthermore, because the duration of the highly plastic maturation period in adult-born neurons could impact the entire neural network of the hippocampus through feedforward and feedback mechanisms (Toda et al., 2018), it is critical to determine the duration of the maturation period to estimate the role of adult-born neurons in the human hippocampus. Although it is difficult to conduct these experiments using human brains, combining recently developed hippocampal organoids with a transplant strategy may allow us to address this issue (Sakaguchi et al., 2015; Mansour et al., 2018). An alternative approach will be noninvasive in vivo imaging of neurogenesis using nuclear magnetic resonance spectroscopy or positron emission tomography (Manganas et al., 2007; Rueger et al., 2010; Tamura et al., 2016). These technologies are still under development, and the methodology needs to be refined to increase the spatial resolution and specificity of detection. Stem cell technology can help to identify specific markers of adult neural stem cells and adult-born neurons that could be used for noninvasive in vivo imaging. Advances in these technologies will also allow us to identify cognitive metrics relating to adult hippocampal neurogenesis in humans. In addition, this line of study has the potential to identify biomarkers for the reduction of adult neurogenesis, which could be beneficial for clinical screening.

Third, we need to identify the roles of adult hippocampal neurogenesis in humans in both physiological and pathological conditions. Accumulating evidence using animal models has uncovered significant roles for adult-born neurons in cognitive function and mood regulation (Shors et al., 2001; Kropff et al., 2015; Aimone, 2016; Anacker and Hen, 2017; Toda and Gage, 2018). In contrast, evidence linking adult hippocampal neurogenesis to cognitive function in humans is still limited and indirect (Toda et al., 2018). Although it is hard to manipulate the levels of adult neurogenesis in the human brain, the development of noninvasive in vivo functional imaging at cellular resolution would help to monitor neural activity of adult-born neurons and their contribution in cognitive function and mood regulation. Further technical development is desperately needed to advance our understanding.

Fourth, the mechanisms underlying the development and maintenance of the neurogenic niche in the subgranular zone of the DG are still unclear. Although past achievements in the field have revealed a number of essential factors in the maintenance of neurogenic capability, it is still totally unclear why specific regions of the brain, such as the subgranular zone, can possess and maintain neurogenic properties. What are the cellular and molecular components necessary for the development and maintenance of neurogenic regions in the adult brain? Since recent evidence suggests that systemic factors in serum contribute to the regulation of adult neurogenesis, the neurogenic niche may be involved not only in local cellular/tissue components within the DG, but also in other organs; even the microbiota of the gut may contribute as remote components of the neurogenic niche (Ogbonnaya et al., 2015). It would be intriguing to examine how other organs contribute to the maintenance of the neurogenic niche in the DG and how aging affects these communications.

Fifth, the cell-autonomous mechanisms underlying the longterm maintenance of multipotency/quiescence of adult neural stem cells need to be determined. The importance of cell cycle regulators as well as transcriptional/epigenetic factors has been investigated (Gonçalves et al., 2016a; Toda et al., 2018). However, most adult neural stem cells maintain a quiescent state despite the fact that a variety of stimuli in the niche can activate them; therefore, one can assume that there are very robust cell-autonomous mechanisms underlying the maintenance of the quiescent state. Intriguingly, some nuclear proteins were identified as long-lived proteins, including histones, nuclear lamins, and nucleoporins (Savas et al., 2012; Toyama et al., 2013). These proteins interact with chromatins and work as a structural foundation for celltype-specific gene regulation (Ibarra and Hetzer, 2015; Jacinto et al., 2015; Ibarra et al., 2016; Toda et al., 2017). Because these proteins accumulate damage with age presumably due to their low turnover rates (D'Angelo et al., 2009), they may lead to agedependent deterioration of gene regulation. These mechanisms could be fundamental in maintaining not only adult NSPCs but also the plasticity that is observed to some extent in any somatic stem cells throughout our lifetime.

In conclusion, what started in the early 1990s as an expedition to probe the possible existence of somatic stem cells within the adult brain led to the establishment of a new area of neuroscience research. For adult neurogenesis to receive significant (even though not always undisputed) recognition, the development of novel tools was essential, and they made possible the firm establishment of the phenomenon already described by Altman and colleagues in the 1960s. We were immediately aware that a central dogma of neurobiology, declared by Ramón y Cajal in 1928, "Everything may die, nothing may be regenerated ..." (Ramón y Cajal, 1991) had been repudiated. But even $>20$ years later, the role that adult neurogenesis plays within the context of hippocampal function, neuroplasticity, and brain repair brings up many unsolved questions. We therefore call upon the next generation of scientists to embrace the rest of Ramón y Cajal's famous declaration: ". . . It is for the science of the future to change, if possible, this harsh decree” (Ramón y Cajal, 1991).

\section{References}

Aimone JB (2016) Computational modeling of adult neurogenesis. Cold Spring Harb Perspect Biol 8:a018960. CrossRef Medline

Aizawa K, Ageyama N, Yokoyama C, Hisatsune T (2009) Age-dependent alteration in hippocampal neurogenesis correlates with learning performance of macaque monkeys. Exp Anim 58:403-407. CrossRef Medline

Altman J, Das GD (1965) Autoradiographic and histological evidence of postnatal hippocampal neurogenesis in rats. J Comp Neurol 124:319335. CrossRef Medline

Alvarez DD, Giacomini D, Yang SM, Trinchero MF, Temprana SG, Büttner KA, Beltramone N, Schinder AF (2016) A disynaptic feedback network activated by experience promotes the integration of new granule cells. Science 354:459-465. CrossRef Medline

Anacker C, Hen R (2017) Adult hippocampal neurogenesis and cognitive flexibility: linking memory and mood. Nat Rev Neurosci 18:335-346. CrossRef Medline

Anacker C, Luna VM, Stevens GS, Millette A, Shores R, Jimenez JC, Chen B, Hen R (2018) Hippocampal neurogenesis confers stress resilience by inhibiting the ventral dentate gyrus. Nature 559:98-102. CrossRef Medline

Andersen J, Urbán N, Achimastou A, Ito A, Simic M, Ullom K, Martynoga B, Lebel M, Göritz C, Frisén J, Nakafuku M, Guillemot F (2014) A transcriptional mechanism integrating inputs from extracellular signals to activate hippocampal stem cells. Neuron 83:1085-1097. CrossRef Medline

Arruda-Carvalho M, Sakaguchi M, Akers KG, Josselyn SA, Frankland PW (2011) Posttraining ablation of adult-generated neurons degrades previously acquired memories. J Neurosci 31:15113-15127. CrossRef Medline

Artegiani B, Lyubimova A, Muraro M, van Es JH, van Oudenaarden A, Clevers H (2017) A single-cell RNA sequencing study reveals cellular and molecular dynamics of the hippocampal neurogenic niche. Cell Rep 21:3271-3284. CrossRef Medline

Bayer SA (1983) ${ }^{3} \mathrm{H}$-thymidine-radiographic studies of neurogenesis in the rat olfactory bulb. Exp Brain Res 50:329-340. Medline 
Beckervordersandforth R, Ebert B, Schäffner I, Moss J, Fiebig C, Shin J, Moore DL, Ghosh L, Trinchero MF, Stockburger C, Friedland K, Steib K, von Wittgenstein J, Keiner S, Redecker C, Hölter SM, Xiang W, Wurst W, Jagasia R, Schinder AF, et al. (2017) Role of mitochondrial metabolism in the control of early lineage progression and aging phenotypes in adult hippocampal neurogenesis. Neuron 93:560-573.e6. CrossRef Medline

Bergami M, Masserdotti G, Temprana SG, Motori E, Eriksson TM, Göbel J, Yang SM, Conzelmann KK, Schinder AF, Götz M, Berninger B (2015) A critical period for experience-dependent remodeling of adult-born neuron connectivity. Neuron 85:710-717. CrossRef Medline

Boekhoorn K, Joels M, Lucassen PJ (2006) Increased proliferation reflects glial and vascular-associated changes, but not neurogenesis in the presenile Alzheimer hippocampus. Neurobiol Dis 24:1-14. CrossRef Medline

Boldrini M, Fulmore CA, Tartt AN, Simeon LR, Pavlova I, Poposka V, Rosoklija GB, Stankov A, Arango V, Dwork AJ, Hen R, Mann JJ (2018) Human hippocampal neurogenesis persists throughout aging. Cell Stem Cell 22:589-599.e5. Medline

Bonaguidi MA, Wheeler MA, Shapiro JS, Stadel RP, Sun GJ, Ming GL, Song H (2011) In vivo clonal analysis reveals self-renewing and multipotent adult neural stem cell characteristics. Cell 145:1142-1155. CrossRef Medline

Bonaguidi MA, Song J, Ming GL, Song H (2012) A unifying hypothesis on mammalian neural stem cell properties in the adult hippocampus. Curr Opin Neurobiol 22:754-761. CrossRef Medline

Cahill SP, Yu RQ, Green D, Todorova EV, Snyder JS (2017) Early survival and delayed death of developmentally-born dentate gyrus neurons. Hippocampus 27:1155-1167. CrossRef Medline

Cameron HA, McKay RD (1999) Restoring production of hippocampal neurons in old age. Nat Neurosci 2:894-897. CrossRef Medline

Cameron HA, Woolley CS, McEwen BS, Gould E (1993) Differentiation of newly born neurons and glia in the dentate gyrus of the adult rat. Neuroscience 56:337-344. CrossRef Medline

Cameron HA, McEwen BS, Gould E (1995) Regulation of adult neurogenesis by excitatory input and NMDA receptor activation in the dentate gyrus. J Neurosci 15:4687-4692. CrossRef Medline

Castellano JM, Mosher KI, Abbey RJ, McBride AA, James ML, Berdnik D, Shen JC, Zou B, Xie XS, Tingle M, Hinkson IV, Angst MS, Wyss-Coray T (2017) Human umbilical cord plasma proteins revitalize hippocampal function in aged mice. Nature 544:488-492. CrossRef Medline

Corenblum MJ, Ray S, Remley QW, Long M, Harder B, Zhang DD, Barnes CA, Madhavan L (2016) Reduced Nrf2 expression mediates the decline in neural stem cell function during a critical middle-age period. Aging Cell 15:725-736. CrossRef Medline

D’Angelo MA, Raices M, Panowski SH, Hetzer MW (2009) Age-dependent deterioration of nuclear pore complexes causes a loss of nuclear integrity in postmitotic cells. Cell 136:284-295. CrossRef Medline

Danielson NB, Kaifosh P, Zaremba JD, Lovett-Barron M, Tsai J, Denny CA, Balough EM, Goldberg AR, Drew LJ, Hen R, Losonczy A, Kheirbek MA (2016) Distinct contribution of adult-born hippocampal granule cells to context encoding. Neuron 90:101-112. CrossRef Medline

Danielson NB, Turi GF, Ladow M, Chavlis S, Petrantonakis PC, Poirazi P, Losonczy A (2017) In vivo imaging of dentate gyrus mossy cells in behaving mice. Neuron 93:552-559.e4 CrossRef Medline

Dayer AG, Ford AA, Cleaver KM, Yassaee M, Cameron HA (2003) Shortterm and long-term survival of new neurons in the rat dentate gyrus. J Comp Neurol 460:563-572. CrossRef Medline

Deng W, Saxe MD, Gallina IS, Gage FH (2009) Adult-born hippocampal dentate granule cells undergoing maturation modulate learning and memory in the brain. J Neurosci 29:13532-13542. CrossRef Medline

Deng W, Aimone JB, Gage FH (2010) New neurons and new memories: how does adult hippocampal neurogenesis affect learning and memory? Nat Rev Neurosci 11:339-350. CrossRef Medline

Dennis CV, Suh LS, Rodriguez ML, Kril JJ, Sutherland GT (2016) Human adult neurogenesis across the ages: an immunohistochemical study. Neuropathol Appl Neurobiol 42:621-638. CrossRef Medline

Deshpande A, Bergami M, Ghanem A, Conzelmann KK, Lepier A, Götz M, Berninger B (2013) Retrograde monosynaptic tracing reveals the temporal evolution of inputs onto new neurons in the adult dentate gyrus and olfactory bulb. Proc Natl Acad Sci U S A 110:E1152-E1161. CrossRef Medline

Dillon SE, Tsivos D, Knight M, McCann B, Pennington C, Shiel AI, Conway ME, Newson MA, Kauppinen RA, Coulthard EJ (2017) The impact of ageing reveals distinct roles for human dentate gyrus and CA3 in pattern separation and object recognition memory. Sci Rep 7:14069. CrossRef Medline

Dupret D, Revest JM, Koehl M, Ichas F, De Giorgi F, Costet P, Abrous DN, Piazza PV (2008) Spatial relational memory requires hippocampal adult neurogenesis. PLoS One 3:e1959. CrossRef Medline

Encinas JM, Enikolopov G (2008) Identifying and quantitating neural stem and progenitor cells in the adult brain. Methods Cell Biol 85:243-272. CrossRef Medline

Encinas JM, Michurina TV, Peunova N, Park JH, Tordo J, Peterson DA, Fishell G, Koulakov A, Enikolopov G (2011) Division-coupled astrocytic differentiation and age-related depletion of neural stem cells in the adult hippocampus. Cell Stem Cell 8:566-579. CrossRef Medline

Enikolopov G, Overstreet-Wadiche L, Ge S (2015) Viral and transgenic reporters and genetic analysis of adult neurogenesis. Cold Spring Harb Perspect Biol 7:a018804. CrossRef Medline

Eriksson PS, Perfilieva E, Björk-Eriksson T, Alborn AM, Nordborg C, Peterson DA, Gage FH (1998) Neurogenesis in the adult human hippocampus. Nat Med 4:1313-1317. CrossRef Medline

Falkenberg T, Mohammed AK, Henriksson B, Persson H, Winblad B, Lindefors $N$ (1992) Increased expression of brain-derived neurotrophic factor mRNA in rat hippocampus is associated with improved spatial memory and enriched environment. Neurosci Lett 138:153-156. CrossRef Medline

Fan X, Wheatley EG, Villeda SA (2017) Mechanisms of hippocampal aging and the potential for rejuvenation. Annu Rev Neurosci 40:251-272. CrossRef Medline

Gage FH (1994) Challenging an old dogma: neurogenesis in the adult hippocampus. J NIH Res 6:53-55.

Gage FH (2002) Neurogenesis in the adult brain. J Neurosci 22:612-613. CrossRef Medline

Gonçalves JT, Schafer ST, Gage FH (2016a) Adult neurogenesis in the hippocampus: from stem cells to behavior. Cell 167:897-914. CrossRef Medline

Gonçalves JT, Bloyd CW, Shtrahman M, Johnston ST, Schafer ST, Parylak SL, Tran T, Chang T, Gage FH (2016b) In vivo imaging of dendritic pruning in dentate granule cells. Nat Neurosci 19:788-791. CrossRef Medline

Gould E, Cameron HA, Daniels DC, Woolley CS, McEwen BS (1992) Adrenal hormones suppress cell division in the adult rat dentate gyrus. J Neurosci 12:3642-3650. CrossRef Medline

Gould E, Cameron HA, McEwen BS (1994) Blockade of NMDA receptors increases cell death and birth in the developing rat dentate gyrus. J Comp Neurol 340:551-565. CrossRef Medline

Gould E, Tanapat P, McEwen BS, Flügge G, Fuchs E (1998) Proliferation of granule cell precursors in the dentate gyrus of adult monkeys is diminished by stress. Proc Natl Acad Sci U S A 95:3168-3171. CrossRef Medline

Gould E, Beylin A, Tanapat P, Reeves A, Shors TJ (1999a) Learning enhances adult neurogenesis in the hippocampal formation. Nat Neurosci 2:260-265. CrossRef Medline

Gould E, Reeves AJ, Fallah M, Tanapat P, Gross CG, Fuchs E (1999b) Hippocampal neurogenesis in adult old world primates. Proc Natl Acad Sci U S A 96:5263-5267. CrossRef Medline

Gu Y, Arruda-Carvalho M, Wang J, Janoschka SR, Josselyn SA, Frankland PW, Ge S (2012) Optical controlling reveals time-dependent roles for adult-born dentate granule cells. Nat Neurosci 15:1700-1706. CrossRef Medline

Habib N, Li Y, Heidenreich M, Swiech L, Avraham-Davidi I, Trombetta JJ, Hession C, Zhang F, Regev A (2016) Div-seq: single-nucleus RNA-seq reveals dynamics of rare adult newborn neurons. Science 353:925-928. CrossRef Medline

Herrup K, Yang Y (2007) Cell cycle regulation in the postmitotic neuron: oxymoron or new biology? Nat Rev Neurosci 8:368-378. CrossRef Medline

Hochgerner H, Zeisel A, Lönnerberg P, Linnarsson S (2018) Conserved properties of dentate gyrus neurogenesis across postnatal development revealed by single-cell RNA sequencing. Nat Neurosci 21:290-299. CrossRef Medline

Horvath S, Zhang Y, Langfelder P, Kahn RS, Boks MP, van Eijk K, van den Berg LH, Ophoff RA (2012) Aging effects on DNA methylation modules in human brain and blood tissue. Genome Biol 13:R97. CrossRef Medline 
Ibarra A, Hetzer MW (2015) Nuclear pore proteins and the control of genome functions. Genes Dev 29:337-349. CrossRef Medline

Ibarra A, Benner C, Tyagi S, Cool J, Hetzer MW (2016) Nucleoporinmediated regulation of cell identity genes. Genes Dev 30:2253-2258. CrossRef Medline

Imayoshi I, Sakamoto M, Ohtsuka T, Takao K, Miyakawa T, Yamaguchi M, Mori K, Ikeda T, Itohara S, Kageyama R (2008) Roles of continuous neurogenesis in the structural and functional integrity of the adult forebrain. Nat Neurosci 11:1153-1161. CrossRef Medline

Imayoshi I, Isomura A, Harima Y, Kawaguchi K, Kori H, Miyachi H, Fujiwara T, Ishidate F, Kageyama R (2013) Oscillatory control of factors determining multipotency and fate in mouse neural progenitors. Science 342: 1203-1208. CrossRef Medline

Jacinto FV, Benner C, Hetzer MW (2015) The nucleoporin Nup153 regulates embryonic stem cell pluripotency through gene silencing. Genes Dev 29:1224-1238. CrossRef Medline

Jaeger BN, Linker SB, Parylak SL, Barron JJ, Gallina IS, Saavedra CD, Fitzpatrick C, Lim CK, Schafer ST, Lacar B, Jessberger S, Gage FH (2018) A novel environment-evoked transcriptional signature predicts reactivity in single dentate granule neurons. Nat Commun 9:3084. CrossRef Medline

Jessberger S, Toni N, Clemenson GD Jr, Ray J, Gage FH (2008) Directed differentiation of hippocampal stem/progenitor cells in the adult brain. Nat Neurosci 11:888-893. CrossRef Medline

Jhaveri DJ, O'Keeffe I, Robinson GJ, Zhao QY, Zhang ZH, Nink V, Narayanan RK, Osborne GW, Wray NR, Bartlett PF (2015) Purification of neural precursor cells reveals the presence of distinct, stimulus-specific subpopulations of quiescent precursors in the adult mouse hippocampus. J Neurosci 35:8132-8144. CrossRef Medline

Jobe EM, McQuate AL, Zhao X (2012) Crosstalk among epigenetic pathways regulates neurogenesis. Front Neurosci 6:59. CrossRef Medline

Kang W, Hébert JM (2015) FGF signaling is necessary for neurogenesis in young mice and sufficient to reverse its decline in old mice. J Neurosci 35:10217-10223. CrossRef Medline

Kaplan MS, Hinds JW (1977) Neurogenesis in the adult rat: electron microscopic analysis of light radioautographs. Science 197:1092-1094. CrossRef Medline

Kempermann G (2015) Activity dependency and aging in the regulation of adult neurogenesis. Cold Spring Harb Perspect Biol 7:a018929. CrossRef Medline

Kempermann G, Kuhn HG, Gage FH (1997) More hippocampal neurons in adult mice living in an enriched environment. Nature 386:493-495. CrossRef Medline

Kempermann G, Kuhn HG, Gage FH (1998) Experience-induced neurogenesis in the senescent dentate gyrus. J Neurosci 18:3206-3212. CrossRef Medline

Kempermann G, Gast D, Gage FH (2002) Neuroplasticity in old age: sustained fivefold induction of hippocampal neurogenesis by long-term environmental enrichment. Ann Neurol 52:135-143. CrossRef Medline

Kempermann G, Gast D, Kronenberg G, Yamaguchi M, Gage FH (2003) Early determination and long-term persistence of adult-generated new neurons in the hippocampus of mice. Development 130:391-399. CrossRef Medline

Kempermann G, Gage FH, Aigner L, Song H, Curtis MA, Thuret S, Kuhn HG, Jessberger S, Frankland PW, Cameron HA, Gould E, Hen R, Abrous DN, Toni N, Schinder AF, Zhao X, Lucassen PJ, Frisén J (2018) Human adult neurogenesis: evidence and remaining questions. Cell Stem Cell 23:2530. CrossRef Medline

Kirschen GW, Shen J, Tian M, Schroeder B, Wang J, Man G, Wu S, Ge S (2017) Active dentate granule cells encode experience to promote the addition of adult-born hippocampal neurons. J Neurosci 37:4661-4678. CrossRef Medline

Knoth R, Singec I, Ditter M, Pantazis G, Capetian P, Meyer RP, Horvat V, Volk B, Kempermann G (2010) Murine features of neurogenesis in the human hippocampus across the lifespan from 0 to 100 years. PLoS One 5:e8809. CrossRef Medline

Kobilo T, Liu QR, Gandhi K, Mughal M, Shaham Y, van Praag H (2011) Running is the neurogenic and neurotrophic stimulus in environmental enrichment. Learn Mem 18:605-609. CrossRef Medline

Kohler SJ, Williams NI, Stanton GB, Cameron JL, Greenough WT (2011) Maturation time of new granule cells in the dentate gyrus of adult macaque monkeys exceeds six months. Proc Natl Acad Sci U S A 108:1032610331. CrossRef Medline
Kornack DR, Rakic P (1999) Continuation of neurogenesis in the hippocampus of the adult macaque monkey. Proc Natl Acad Sci U S A 96: 5768-5773. CrossRef Medline

Kronenberg G, Bick-Sander A, Bunk E, Wolf C, Ehninger D, Kempermann G (2006) Physical exercise prevents age-related decline in precursor cell activity in the mouse dentate gyrus. Neurobiol Aging 27:1505-1513. CrossRef Medline

Kropff E, Yang SM, Schinder AF (2015) Dynamic role of adult-born dentate granule cells in memory processing. Curr Opin Neurobiol 35:21-26. CrossRef Medline

Kuhn HG, Cooper-Kuhn CM (2007) Bromodeoxyuridine and the detection of neurogenesis. Curr Pharm Biotechnol 8:127-131. CrossRef Medline

Kuhn HG, Dickinson-Anson H, Gage FH (1996) Neurogenesis in the dentate gyrus of the adult rat: age-related decrease of neuronal progenitor proliferation. J Neurosci 16:2027-2033. CrossRef Medline

Kuhn HG, Eisch AJ, Spalding K, Peterson DA (2016) Detection and phenotypic characterization of adult neurogenesis. Cold Spring Harb Perspect Biol 8:a025981. CrossRef Medline

Kuipers SD, Schroeder JE, Trentani A (2015) Changes in hippocampal neurogenesis throughout early development. Neurobiol Aging 36:365-379. CrossRef Medline

Kuzumaki N, Ikegami D, Imai S, Narita M, Tamura R, Yajima M, Suzuki A, Miyashita K, Niikura K, Takeshima H, Ando T, Ushijima T, Suzuki T, Narita M (2010a) Enhanced IL-1beta production in response to the activation of hippocampal glial cells impairs neurogenesis in aged mice. Synapse 64:721-728. CrossRef Medline

Kuzumaki N, Ikegami D, Tamura R, Sasaki T, Niikura K, Narita M, Miyashita K, Imai S, Takeshima H, Ando T, Igarashi K, Kanno J, Ushijima T, Suzuki T, Narita M (2010b) Hippocampal epigenetic modification at the doublecortin gene is involved in the impairment of neurogenesis with aging. Synapse 64:611-616. CrossRef Medline

Lacar B, Linker SB, Jaeger BN, Krishnaswami SR, Barron JJ, Kelder MJ, Parylak SL, Paquola AC, Venepally P, Novotny M, O'Connor C, Fitzpatrick C, Erwin JA, Hsu JY, Husband D, McConnell MJ, Lasken R, Gage FH (2016) Nuclear RNA-seq of single neurons reveals molecular signatures of activation. Nat Commun 7:11022. CrossRef Medline

Lagace DC, Whitman MC, Noonan MA, Ables JL, DeCarolis NA, Arguello AA, Donovan MH, Fischer SJ, Farnbauch LA, Beech RD, DiLeone RJ, Greer CA, Mandyam CD, Eisch AJ (2007) Dynamic contribution of nestin-expressing stem cells to adult neurogenesis. J Neurosci 27:1262312629. CrossRef Medline

Leeman DS, Hebestreit K, Ruetz T, Webb AE, McKay A, Pollina EA, Dulken BW, Zhao X, Yeo RW, Ho TT, Mahmoudi S, Devarajan K, Passegué E, Rando TA, Frydman J, Brunet A (2018) Lysosome activation clears aggregates and enhances quiescent neural stem cell activation during aging. Science 359:1277-1283. CrossRef Medline

Leuner B, Gould E (2010) Structural plasticity and hippocampal function. Annu Rev Psychol 61:111-140, C1-C3. CrossRef Medline

Leuner B, Kozorovitskiy Y, Gross CG, Gould E (2007) Diminished adult neurogenesis in the marmoset brain precedes old age. Proc Natl Acad Sci U S A 104:17169-17173. CrossRef Medline

Lie DC, Colamarino SA, Song HJ, Desiré L, Mira H, Consiglio A, Lein ES, Jessberger S, Lansford H, Dearie AR, Gage FH (2005) Wnt signalling regulates adult hippocampal neurogenesis. Nature 437:1370-1375. CrossRef Medline

Lim DA, Tramontin AD, Trevejo JM, Herrera DG, García-Verdugo JM, Alvarez-Buylla A (2000) Noggin antagonizes BMP signaling to create a niche for adult neurogenesis. Neuron 28:713-726. CrossRef Medline

Lim DA, Huang YC, Swigut T, Mirick AL, Garcia-Verdugo JM, Wysocka J, Ernst P, Alvarez-Buylla A (2009) Chromatin remodelling factor Mll1 is essential for neurogenesis from postnatal neural stem cells. Nature 458: 529-533. CrossRef Medline

Lugert S, Basak O, Knuckles P, Haussler U, Fabel K, Götz M, Haas CA, Kempermann G, Taylor V, Giachino C (2010) Quiescent and active hippocampal neural stem cells with distinct morphologies respond selectively to physiological and pathological stimuli and aging. Cell Stem Cell 6:445-456. CrossRef Medline

Manganas LN, Zhang X, Li Y, Hazel RD, Smith SD, Wagshul ME, Henn F, Benveniste H, Djuric PM, Enikolopov G, Maletic-Savatic M (2007) Magnetic resonance spectroscopy identifies neural progenitor cells in the live human brain. Science 318:980-985. CrossRef Medline 
Mansour AA, Gonçalves JT, Bloyd CW, Li H, Fernandes S, Quang D, Johnston S, Parylak SL, Jin X, Gage FH (2018) An in vivo model of functional and vascularized human brain organoids. Nat Biotechnol 36:432-441. CrossRef Medline

Mathews KJ, Allen KM, Boerrigter D, Ball H, Shannon Weickert C, Double KL (2017) Evidence for reduced neurogenesis in the aging human hippocampus despite stable stem cell markers. Aging Cell 16:1195-1199. CrossRef Medline

McAvoy KM, Scobie KN, Berger S, Russo C, Guo N, Decharatanachart P, Vega-Ramirez H, Miake-Lye S, Whalen M, Nelson M, Bergami M, Bartsch D, Hen R, Berninger B, Sahay A (2016) Modulating neuronal competition dynamics in the dentate gyrus to rejuvenate aging memory circuits. Neuron 91:1356-1373. CrossRef Medline

Mirescu C, Peters JD, Gould E (2004) Early life experience alters response of adult neurogenesis to stress. Nat Neurosci 7:841-846. CrossRef Medline

Molofsky AV, Slutsky SG, Joseph NM, He S, Pardal R, Krishnamurthy J, Sharpless NE, Morrison SJ (2006) Increasing p16INK4a expression decreases forebrain progenitors and neurogenesis during ageing. Nature 443:448-452. CrossRef Medline

Moore DL, Pilz GA, Arauzo-Bravo MJ, Barral Y, Jessberger S (2015) A mechanism for the segregation of age in mammalian neural stem cells. Science 349:1334-1338. CrossRef Medline

Morshead CM, Reynolds BA, Craig CG, McBurney MW, Staines WA, Morassutti D, Weiss S, van der Kooy D (1994) Neural stem cells in the adult mammalian forebrain: a relatively quiescent subpopulation of subependymal cells. Neuron 13:1071-1082. CrossRef Medline

Morshead CM, Craig CG, van der Kooy D (1998) In vivo clonal analyses reveal the properties of endogenous neural stem cell proliferation in the adult mammalian forebrain. Development 125:2251-2261. Medline

Mosher KI, Schaffer DV (2018) Influence of hippocampal niche signals on neural stem cell functions during aging. Cell Tissue Res 371:115-124. CrossRef Medline

Ogbonnaya ES, Clarke G, Shanahan F, Dinan TG, Cryan JF, O'Leary OF (2015) Adult hippocampal neurogenesis is regulated by the microbiome. Biol Psychiatry 78:e7-e9. CrossRef Medline

Okamoto M, Inoue K, Iwamura $\mathrm{H}$, Terashima K, Soya $\mathrm{H}$, Asashima M, Kuwabara T (2011) Reduction in paracrine Wnt3 factors during aging causes impaired adult neurogenesis. FASEB J 25:3570-3582. CrossRef Medline

Oliff HS, Berchtold NC, Isackson P, Cotman CW (1998) Exercise-induced regulation of brain-derived neurotrophic factor (BDNF) transcripts in the rat hippocampus. Brain Res Mol Brain Res 61:147-153. CrossRef Medline

Overstreet-Wadiche LS, Bensen AL, Westbrook GL (2006) Delayed development of adult-generated granule cells in dentate gyrus. J Neurosci 26: 2326-2334. CrossRef Medline

Palmer TD, Ray J, Gage FH (1995) FGF-2-responsive neuronal progenitors reside in proliferative and quiescent regions of the adult rodent brain. Mol Cell Neurosci 6:474-486. CrossRef Medline

Palmer TD, Takahashi J, Gage FH (1997) The adult rat hippocampus contains primordial neural stem cells. Mol Cell Neurosci 8:389-404. CrossRef Medline

Palmer TD, Markakis EA, Willhoite AR, Safar F, Gage FH (1999) Fibroblast growth factor-2 activates a latent neurogenic program in neural stem cells from diverse regions of the adult CNS. J Neurosci 19:8487-8497. CrossRef Medline

Palmer TD, Willhoite AR, Gage FH (2000) Vascular niche for adult hippocampal neurogenesis. J Comp Neurol 425:479-494. CrossRef Medline

Palmer TD, Schwartz PH, Taupin P, Kaspar B, Stein SA, Gage FH (2001) Cell culture. progenitor cells from human brain after death. Nature 411: 42-43. CrossRef Medline

Patzke N, Spocter MA, Karlsson KA, Bertelsen MF, Haagensen M, Chawana R, Streicher S, Kaswera C, Gilissen E, Alagaili AN, Mohammed OB, Reep RL, Bennett NC, Siegel JM, Ihunwo AO, Manger PR (2015) In contrast to many other mammals, cetaceans have relatively small hippocampi that appear to lack adult neurogenesis. Brain Struct Funct 220:361-383. CrossRef Medline

Pilz GA, Carta S, Stäuble A, Ayaz A, Jessberger S, Helmchen F (2016) Functional imaging of dentate granule cells in the adult mouse hippocampus. J Neurosci 36:7407-7414. CrossRef Medline

Pilz GA, Bottes S, Betizeau M, Jörg DJ, Carta S, Simons BD, Helmchen F,
Jessberger S (2018) Live imaging of neurogenesis in the adult mouse hippocampus. Science 359:658-662. CrossRef Medline

Ramón y Cajal S (1991) Cajal's degeneration and regeneration of the nervous system. In: History of neuroscience (DeFelipe J, Jones EG, May RM, eds), pp xvi. New York: Oxford UP.

Ray J, Gage FH (1994) Spinal cord neuroblasts proliferate in response to basic fibroblast growth factor. J Neurosci 14:3548-3564. CrossRef Medline

Ray J, Peterson DA, Schinstine M, Gage FH (1993) Proliferation, differentiation, and long-term culture of primary hippocampal neurons. Proc Natl Acad Sci U S A 90:3602-3606. CrossRef Medline

Renault VM, Rafalski VA, Morgan AA, Salih DA, Brett JO, Webb AE, Villeda SA, Thekkat PU, Guillerey C, Denko NC, Palmer TD, Butte AJ, Brunet A (2009) FoxO3 regulates neural stem cell homeostasis. Cell Stem Cell 5:527-539. CrossRef Medline

Reynolds BA, Weiss S (1992) Generation of neurons and astrocytes from isolated cells of the adult mammalian central nervous system. Science 255:1707-1710. CrossRef Medline

Reynolds BA, Tetzlaff W, Weiss S (1992) A multipotent EGF-responsive striatal embryonic progenitor cell produces neurons and astrocytes. J Neurosci 12:4565-4574. CrossRef Medline

Rost BR, Schneider-Warme F, Schmitz D, Hegemann P (2017) Optogenetic tools for subcellular applications in neuroscience. Neuron 96:572-603. CrossRef Medline

Roy NS, Wang S, Jiang L, Kang J, Benraiss A, Harrison-Restelli C, Fraser RA, Couldwell WT, Kawaguchi A, Okano H, Nedergaard M, Goldman SA (2000) In vitro neurogenesis by progenitor cells isolated from the adult human hippocampus. Nat Med 6:271-277. CrossRef Medline

Rueger MA, Backes H, Walberer M, Neumaier B, Ullrich R, Simard ML, Emig B, Fink GR, Hoehn M, Graf R, Schroeter M (2010) Noninvasive imaging of endogenous neural stem cell mobilization in vivo using positron emission tomography. J Neurosci 30:6454-6460. CrossRef Medline

Sah N, Peterson BD, Lubejko ST, Vivar C, van Praag H (2017) Running reorganizes the circuitry of one-week-old adult-born hippocampal neurons. Sci Rep 7:10903. CrossRef Medline

Sakaguchi H, Kadoshima T, Soen M, Narii N, Ishida Y, Ohgushi M, Takahashi J, Eiraku M, Sasai Y (2015) Generation of functional hippocampal neurons from self-organizing human embryonic stem cell-derived dorsomedial telencephalic tissue. Nat Commun 6:8896. CrossRef Medline

Savas JN, Toyama BH, Xu T, Yates JR 3rd, Hetzer MW (2012) Extremely long-lived nuclear pore proteins in the rat brain. Science 335:942. CrossRef Medline

Shi Y, Chichung Lie D, Taupin P, Nakashima K, Ray J, Yu RT, Gage FH, Evans RM (2004) Expression and function of orphan nuclear receptor TLX in adult neural stem cells. Nature 427:78-83. CrossRef Medline

Shin J, Berg DA, Zhu Y, Shin JY, Song J, Bonaguidi MA, Enikolopov G, Nauen DW, Christian KM, Ming GL, Song H (2015) Single-cell RNA-seq with waterfall reveals molecular cascades underlying adult neurogenesis. Cell Stem Cell 17:360-372. CrossRef Medline

Shors TJ, Miesegaes G, Beylin A, Zhao M, Rydel T, Gould E (2001) Neurogenesis in the adult is involved in the formation of trace memories. Nature 410:372-376. CrossRef Medline

Smith LK, He Y, Park JS, Bieri G, Snethlage CE, Lin K, Gontier G, Wabl R, Plambeck KE, Udeochu J, Wheatley EG, Bouchard J, Eggel A, Narasimha R, Grant JL, Luo J, Wyss-Coray T, Villeda SA (2015) $\beta 2$-microglobulin is a systemic pro-aging factor that impairs cognitive function and neurogenesis. Nat Med 21:932-937. CrossRef Medline

Smith LK, White CW 3rd, Villeda SA (2018) The systemic environment: at the interface of aging and adult neurogenesis. Cell Tissue Res 371:105113. CrossRef Medline

Snyder JS, Soumier A, Brewer M, Pickel J, Cameron HA (2011) Adult hippocampal neurogenesis buffers stress responses and depressive behaviour. Nature 476:458-461. CrossRef Medline

Sorrells SF, Paredes MF, Cebrian-Silla A, Sandoval K, Qi D, Kelley KW, James D, Mayer S, Chang J, Auguste KI, Chang EF, Gutierrez AJ, Kriegstein AR, Mathern GW, Oldham MC, Huang EJ, Garcia-Verdugo JM, Yang Z, Alvarez-Buylla A (2018) Human hippocampal neurogenesis drops sharply in children to undetectable levels in adults. Nature 555:377-381. CrossRef Medline

Spalding KL, Bergmann O, Alkass K, Bernard S, Salehpour M, Huttner HB, Boström E, Westerlund I, Vial C, Buchholz BA, Possnert G, Mash DC, 
Druid H, Frisén J (2013) Dynamics of hippocampal neurogenesis in adult humans. Cell 153:1219-1227. CrossRef Medline

Speisman RB, Kumar A, Rani A, Pastoriza JM, Severance JE, Foster TC, Ormerod BK (2013) Environmental enrichment restores neurogenesis and rapid acquisition in aged rats. Neurobiol Aging 34:263-274. CrossRef Medline

Stangl D, Thuret S (2009) Impact of diet on adult hippocampal neurogenesis. Genes Nutr 4:271-282. CrossRef Medline

Suh H, Consiglio A, Ray J, Sawai T, D’Amour KA, Gage FH (2007) In vivo fate analysis reveals the multipotent and self-renewal capacities of Sox ${ }^{2+}$ neural stem cells in the adult hippocampus. Cell Stem Cell 1:515-528. CrossRef Medline

Tamura Y, Takahashi K, Takata K, Eguchi A, Yamato M, Kume S, Nakano M, Watanabe Y, Kataoka Y (2016) Noninvasive evaluation of cellular proliferative activity in brain neurogenic regions in rats under depression and treatment by enhanced $\left[{ }^{18}\right.$ F]FLT-PET imaging. J Neurosci 36:81238131. CrossRef Medline

Tashiro A, Sandler VM, Toni N, Zhao C, Gage FH (2006) NMDA-receptormediated, cell-specific integration of new neurons in adult dentate gyrus. Nature 442:929-933. CrossRef Medline

Temprana SG, Mongiat LA, Yang SM, Trinchero MF, Alvarez DD, Kropff E, Giacomini D, Beltramone N, Lanuza GM, Schinder AF (2015) Delayed coupling to feedback inhibition during a critical period for the integration of adult-born granule cells. Neuron 85:116-130. CrossRef Medline

Toda T, Gage FH (2018) Review: adult neurogenesis contributes to hippocampal plasticity. Cell Tissue Res 373:693-709. CrossRef Medline

Toda T, Hsu JY, Linker SB, Hu L, Schafer ST, Mertens J, Jacinto FV, Hetzer MW, Gage FH (2017) Nup153 interacts with Sox2 to enable bimodal gene regulation and maintenance of neural progenitor cells. Cell Stem Cell 21:618-634.e7. CrossRef Medline

Toda T, Parylak SL, Linker SB, Gage FH (2018) The role of adult hippocampal neurogenesis in brain health and disease. Mol Psychiatry. Advance online publication. Retrieved Apr. 20, 2018. doi: 10.1038/s41380-0180036-2. CrossRef Medline

Toyama BH, Savas JN, Park SK, Harris MS, Ingolia NT, Yates JR 3rd, Hetzer MW (2013) Identification of long-lived proteins reveals exceptional stability of essential cellular structures. Cell 154:971-982. CrossRef Medline

Trinchero MF, Büttner KA, Sulkes Cuevas JN, Temprana SG, Fontanet PA, Monzón-Salinas MC, Ledda F, Paratcha G, Schinder AF (2017) High plasticity of new granule cells in the aging hippocampus. Cell Rep 21: 1129-1139. CrossRef Medline

Urbán N, Guillemot F (2014) Neurogenesis in the embryonic and adult brain: same regulators, different roles. Front Cell Neurosci 8:396. CrossRef Medline

van Praag H, Kempermann G, Gage FH (1999) Running increases cell proliferation and neurogenesis in the adult mouse dentate gyrus. Nat Neurosci 2:266-270. CrossRef Medline van Praag H, Schinder AF, Christie BR, Toni N, Palmer TD, Gage FH (2002) Functional neurogenesis in the adult hippocampus. Nature 415:1030 1034. CrossRef Medline

van Praag H, Shubert T, Zhao C, Gage FH (2005) Exercise enhances learning and hippocampal neurogenesis in aged mice. J Neurosci 25:86808685. CrossRef Medline

Villeda SA, Luo J, Mosher KI, Zou B, Britschgi M, Bieri G, Stan TM, Fainberg N, Ding Z, Eggel A, Lucin KM, Czirr E, Park JS, Couillard-Després S, Aigner L, Li G, Peskind ER, Kaye JA, Quinn JF, Galasko DR, et al. (2011) The ageing systemic milieu negatively regulates neurogenesis and cognitive function. Nature 477:90-94. CrossRef Medline

Villeda SA, Plambeck KE, Middeldorp J, Castellano JM, Mosher KI, Luo J, Smith LK, Bieri G, Lin K, Berdnik D, Wabl R, Udeochu J, Wheatley EG, Zou B, Simmons DA, Xie XS, Longo FM, Wyss-Coray T (2014) Young blood reverses age-related impairments in cognitive function and synaptic plasticity in mice. Nat Med 20:659-663. CrossRef Medline

Vivar C, Potter MC, Choi J, Lee JY, Stringer TP, Callaway EM, Gage FH, Suh $\mathrm{H}$, van Praag H (2012) Monosynaptic inputs to new neurons in the dentate gyrus. Nat Commun 3:1107. CrossRef Medline

Vivar C, Potter MC, van Praag H (2013) All about running: synaptic plasticity, growth factors and adult hippocampal neurogenesis. Curr Top Behav Neurosci 15:189-210. CrossRef Medline

Wickersham IR, Lyon DC, Barnard RJ, Mori T, Finke S, Conzelmann KK, Young JA, Callaway EM (2007) Monosynaptic restriction of transsynaptic tracing from single, genetically targeted neurons. Neuron 53:639647. CrossRef Medline

Yamaguchi M, Saito H, Suzuki M, Mori K (2000) Visualization of neurogenesis in the central nervous system using nestin promoter-GFP transgenic mice. Neuroreport 11:1991-1996. CrossRef Medline

Yassa MA, Lacy JW, Stark SM, Albert MS, Gallagher M, Stark CE (2011) Pattern separation deficits associated with increased hippocampal CA3 and dentate gyrus activity in nondemented older adults. Hippocampus 21:968-979. CrossRef Medline

Yousef H, Morgenthaler A, Schlesinger C, Bugaj L, Conboy IM, Schaffer DV (2015) Age-associated increase in BMP signaling inhibits hippocampal neurogenesis. Stem Cells 33:1577-1588. CrossRef Medline

Yuzwa SA, Borrett MJ, Innes BT, Voronova A, Ketela T, Kaplan DR, Bader GD, Miller FD (2017) Developmental emergence of adult neural stem cells as revealed by single-cell transcriptional profiling. Cell Rep 21:3970 3986. CrossRef Medline

Zhao C, Teng EM, Summers RG Jr, Ming GL, Gage FH (2006) Distinct morphological stages of dentate granule neuron maturation in the adult mouse hippocampus. J Neurosci 26:3-11. CrossRef Medline

Zhuo JM, Tseng HA, Desai M, Bucklin ME, Mohammed AI, Robinson NT, Boyden ES, Rangel LM, Jasanoff AP, Gritton HJ, Han X (2016) Young adult born neurons enhance hippocampal dependent performance via influences on bilateral networks. eLife 5:e22429. CrossRef Medline 